Journal of Indonesian Economy and Business

Volume 34, Number 1, 2019, 18- 36

\title{
TARIFF ELIMINATION UNDER THE TRANS-PACIFIC PARTNERSHIP AND ITS IMPACT ON INDONESIA'S TRADE BALANCE
}

\author{
Pritish Kumar Sahu* \\ Economics and Quantitative Analysis Unit (Faculty of Business), Multimedia University, \\ Melaka, 75450, Malaysia
}

\begin{abstract}
Introduction: Indonesia has signed, and is in the process of signing, many bilateral and regional Free Trade Agreements (FTAs). Whether these trade agreements will benefit Indonesia on the economic front or not is still a matter for discussion. Background Problem: Signing TPP, raises many questions as to how this would affect the countries in Asian regions, including Indonesia. Novelty: Considering the criticism of CGE (Computer General Equilibrium) model, this paper uses the SMART simulation model, based on a partial equilibrium approach, to estimate the aggregate and commodity-level gains and losses for Indonesia with its partner countries during the post-tariff elimination period. Research Method: This study uses the World Bank's World Integrated Trade Solution (WITS) Database. This database contains trade data for all the countries under a different nomenclature viz. at the two-digit, four-digit, and six-digit level. We use the HS-classified nomenclature at the six-digit level in order to estimate the impact of the removal of tariffs on Indonesia's trade, i.e. both exports and imports. Findings: The finding reveals that if Indonesia does not take part in the Trans-Pacific Partnership Agreement, it will still have a trade surplus of $\$ 1.6$ billion with the Trans-Pacific countries but joining the bloc would result in a trade deficit of $\$ 19$ million. Joining the bloc would increase the imports from Japan, followed by the United States and Australia as against an increase in exports to the United States, followed by Malaysia and Vietnam. The post Trans-Pacific Partnership period will have many implications for Indonesia, it may face difficulties exporting to the member countries, even with an existing trade agreement, while in the long run the Trans-Pacific Partnership bloc could limit Indonesia's trade prospects with these Pacific Rim countries and it may limit Indonesia influencing WTO outcomes. Conclusion: Trade agreements seem to have benefited Indonesia's economy and its people in many ways over the years, even though it has an important cost for some people.
\end{abstract}

ARTICLE INFO

\footnotetext{
* Corresponding author at Economics and Quantitative Analysis Unit (Faculty of Business), Multimedia University, Melaka, 75450, Malaysia.

E-mail address: (pritishkumar9@gmail.com)
} 


\section{INTRODUCTION}

Indonesia has signed, and is in the process of signing, many bilateral and regional Free Trade Agreements (FTAs). Whether these trade agreements will benefit Indonesia on the economic front or not is still a matter for discussion. But the signing of the Trans-Pacific Partnership $^{1}$ (TPP) agreement raises many questions as to how this would affect the countries in the Asian region, particularly Indonesia. Given the fact that the TPP bloc is comprised of countries with a combined GDP of over $40 \%$ and a population share over $11 \%$ (World Bank Database, 2017), it raises concerns about trade creation and diversion for the nonparticipating countries in the region, including Indonesia.

In this context, it is important to assess the implications of the Trans-Pacific Partnership Agreement (TPPA) post its implementation, particularly after the domestic ratification process has been completed. The TPPA goes far beyond trade and tariff negotiations, as it includes 29 chapters ranging from issues dealing with market access, technical barriers to trade, sanitary and phytosanitary measures, rules of origin, customs cooperation, investment, services and legal and institutional aspects of the negotiation, and also includes government procurement, competition, intellectual property, labor and environmental issues (Banga and Sahu, 2015). The legal texts cover all the aspects of commercial relations among the TPPA countries, and they were signed on February 4, 2016 (Chow, 2016). Given the confidentiality of the agreement, the provisions in most of the

\footnotetext{
${ }^{1}$ TPP includes Australia, Brunei, Canada, Chile, Japan, Malaysia, Mexico, New Zealand, Peru, Singapore, United States and Vietnam. The negotiations on this deal concluded on October 5, 2015, and was signed on February 4, 2016, after 19 rounds of tough negotiations over the span of five years. The partner countries are at present into the domestic ratification process before the agreements enters into force in early 2018.
}

chapters have remained out of the public domain. Available texts $\left(\mathrm{CPTPP}^{2}\right)$ in the context of the investment provisions indicate the formation of legal protection for the investment and the investors of each of the ТPP partners. The TPPA envisages elevating individual foreign firms to equal status with the sovereign nations. The negotiations aim at providing the investors with a non-discriminatory and minimum standard of treatment, and restrict the performance requirements for foreign investments. The text aims to include provisions for expeditious, investor-state dispute settlement. Although the investment chapter has not been officially released by the trade negotiators, the available document reveals that the TPPA would restrict the signatories from regulating foreign firms operating within their boundaries, nor can they regulate the provisions to acquire land, natural resources, or factories, or the right to move capital without limits for foreign investors, without adequate government review (Petri and Michael, 2012). On cross border services, the TPP partner countries have agreed on most of the cross border service's text that is likely to include an open market for services trading (Petri et, al., 2012). Although each of these issues needs to be analyzed in detail, the trade implications of the TPPA are important for Indonesia, mainly because of the involvement of many big economies (such as the USA, Australia, Japan, and Canada) in the TPPA, which are traditionally the major trading partners with Indonesia. Given this, the present paper estimates the impact of eliminating tariffs on Indonesia's exports and imports during the post TPPA scenario. In other words, it finds whether the post TPPA scenario helps or hurts Indonesia's trade balance under the assumption

\footnotetext{
${ }^{2}$ CPTPP- Full text of the Comprehensive and Progressive Agreement for Trans-Pacific Partnership, http://wtocenter.vn/tpp/full-text-comprehensive-andprogressive-agreement-trans-pacific-partnership-cptpp
} 
of complete tariff elimination between the countries party to the agreement. A detailed analysis is undertaken to estimate the extent of the trade diversion that may take place for the member countries, which may adversely affect Indonesia's exports to these countries. Further, a quantitative assessment is undertaken to study the rise in exports and imports to/from different member countries in case Indonesia becomes a member of the TPPA. The analysis is undertaken at the $\mathrm{HS}^{3}$ six-digit disaggregation level to find the extent of the gain/loss at the product level with different TPP countries.

While the overall impact is ambiguous at this stage, the majority of studies (e.g. Petri et al, 2012; Deardorff, 2013; Gajdos, 2013) find that the present TPP deal would adversely affect many economically important countries in the region, including Indonesia. Precisely, the existing literature (such as Petri et al, 2012; Deardorff, 2013; Gajdos, 2013; Xin, 2014) which is limited in nature due to the confidentiality clause in the negotiations, has not thrown much light on matters for the non-participating countries; particularly as there is virtually no empirical literature that focuses exclusively on the impact of TPP on Indonesia's trade or any other macroeconomic indicators. To a certain extent, some of the existing studies (Bergsten; 2015, Cororation and Orden; 2015, Deardorff; 2013, Petri et al; 2012, Cheong; 2013) try to assess the economic gains and losses for several of the participating and non-participating countries, including Indonesia, under different scenarios. Significantly, these studies (Bergsten; 2015, Cororation and Orden; 2015, Deardorff; 2013, Petri et al; 2012, Cheong; 2013) reveal

\footnotetext{
${ }^{3}$ It is Harmonized Commodity Description and Coding System or simply known as Harmonized System (HS). It is an international nomenclature for the classification of products at the international level. The HS for classifying goods at a disaggregation level is a six-digit code system.
}

that the present TPP would bring economic losses to Indonesia and other non-participating ASEAN countries like Thailand, Cambodia, and the Philippines, if they remain out of the negotiations. The lack of a distinct analysis of the TPP's effect on Indonesia has necessitated an early analysis of the likely impacts of joining or not joining the TPP.

The paper is structured as follows: Section 2 provides a brief review of the existing literature and critically evaluates the drawbacks of CGE framework in such analysis. Section 3 discusses the methodology and data used. Section 4 reports the trends in Indonesia's trade with the TPP partners at the country level and at the product level. Section 5 broadly shows the existing trade agreements and tariff pattern with the TPP blocs. Section 6 presents two sets of results, first, Indonesia's loss of exports at the product-level and the country-level if it does not join the TPPA, second, Indonesia's likely rise in exports and imports if it joins TPPA. Section 7 concludes the finding with some likely impact in the post TPP scenarios.

\section{LITERATURE REVIEW}

There is a large amount of literature discussing the impact of various trade agreements on several macroeconomic indicators of the participating countries. But precisely, the literature on the impact of the Trans-Pacific Partnership is limited in nature because of the confidentiality clause in the negotiations. Despite this, several studies (Bergsten; 2015, Petri et al; 2011, Cheong; 2013, Xin; 2014, Deardorff; 2013, and Kenichi; 2011) use the Computable General Equilibrium (CGE) model with the Global Trade Analysis Projects (GTAP) Database for the quantitative assessments for likely gains and losses during the post TPP scenario for both the participating and the nonparticipating countries. 
Studies using the CGE framework in the estimation of the impact of the TPP on the participating and the non-participating countries primarily focused on three basic findings viz. trade creation and diversion, income effect and the welfare effect for each country. Despite the growing literature on the shortcomings of the CGE modeling (Taylor and Arnim; 2006, Charlton and Stiglitz; 2005, Panagariya and Duttagupta; 2001, Raza et al; 2014, Bertram and Terry; 2014), the majority of these studies in this context have used the CGE model to estimate the impact of the TPP on the participating and the major non-participating countries. We have not come across any empirical study which exclusively studies the impact of the TPP on Indonesia if (or if not) it joins the negotiations. However, many of the existing studies, in one way or another, assess the possible economic losses and gains for Indonesia if it becomes a party to the negations or opts out of them.

Cheong's (2013) estimations, using a recursive dynamic CGE model in three different scenarios ${ }^{4}$ reveals that an expansion of the TPP would bring a larger economic loss to Indonesia and the other non-participating ASEAN countries like Thailand and Vietnam. The results suggest that the economic losses of the rest of the ASEAN countries increase to $0.37 \%$ of GDP as a sub-region of ASEAN. Petri, Plummer, and Zhai (2011) examined the benefits and the gains generated by three tracks, namely the TPP track, the Asian track and the FTAAP (Free Trade Area of the Asia Pacific) over 2010-2025. The study reveals that the income for Indonesia under the present TPP track would decline by US\$ -3.5 billion by the year end of 2025 (at constant 2007 prices). On the other hand, Indonesia is likely to gain substantially under the

\footnotetext{
${ }^{4}$ viz. TPP9 members (Australia, Brunei Darussalam, Chile, Malaysia, New Zealand, Peru, Singapore, United States, Vietnam), TPP12 members (TPP9+ Canada, Mexico and Japan) and TPP12+ China (13 members)
}

Asian track and FTAAP by an estimated US\$12.8 billion and US\$38 billion respectively by the year 2025. Similarly, export changes under different scenarios show that Indonesia would make a loss of US\$5.6 billion under the present TPP as against a gain of US\$32.6 billion and US\$97.4 billion under the Asian track and FTAAP respectively.

Gajdos (2013) estimated the potential economic gains for all the participating countries under three alternative scenarios ${ }^{5}$. Although none of these scenarios specifically analyzed the gain to Indonesia, but the economic analysis reveals that there would be an overall gain (both in income and exports) for the TPP countries in the alternative track involving Indonesia (TPP16). The results show the income gain in the TPP16 scenario will be $63 \%$ higher and the export gain will be 95\% higher, over the TPP13 scenario. Deardorff (2013), while estimating the trade implication of TPP on the ASEAN economies, argues its effect by taking the existing trade relations of each country with the present TPP signatories. On the basis of export and import figures, he finds that among the countries in the AFTA (ASEAN Free Trade Area), but not in the TPP, countries viz. Cambodia, Indonesia, the Philippines, and Thailand will be harmed the most by its implementation, provided they opt out of the negotiations.

Cororation and Orden (2015), while estimating the potential economic effect of the TPP on the Philippines, included Indonesia as an important country in the region. Their study, using the GTAP database and CGE modeling finds the trade effects on Indonesia under the TPP scenario. It finds that the exports from Indonesia to the TPP would decline by US $\$ 0.07$

\footnotetext{
'TPP11', present TPP countries excluding Japan ; 'TPP13', which includes TPP11 as well as Japan and South Korea; and 'TPP16', which consists of TPP13 and Indonesia, the Philippines and Thailand.
} 
billion in 2015 and this decline would grow to US $\$ 0.86$ billion by the end of $2024^{6}$. In the present TPP scenario, this trade effect on Indonesia is the highest among the ASEAN countries. At the same time, it finds that exports within the non-TPP countries increase, but not enough to offset the drop in exports to the TPP. The new estimation by Petri and Plummer (2016) finds the impact of the TPP on the participant and the non-participating countries using a CGE framework. Based on the GTAP 9 database for 19 sectors and 29 regions, it shows that the TPP is likely to increase annual real incomes by US $\$ 131$ billion for the US $(0.5 \%$ of GDP) and annual exports by US $\$ 357$ billion (9.1\% of exports) over projections by 2030. It finds Indonesia, as a non-member, will lose US\$2 billion in real income by the year 2030 .

Though these studies have used Computable General Equilibrium (CGE) modeling to find the impact of regional trade agreements on both the included and the excluded countries, the growing criticism of CGE modeling has witnessed the use of the partial equilibrium approach in recent trade agreement studies. Studies by Banga (2014, 2015), for Malaysia and Vietnam respectively and Banga and Sahu (2015) for India have used the partial equilibrium approach to access the impact of the TPPA. These studies have cited the limitation of CGE modeling and its unrealistic assumptions, which invariably lead to the "over-estimation" of gains, especially for small developing countries. The limitations of CGE modeling are well captured in studies viz. Taylor and Arnim (2006), Panagariya and Duttagupta (2001), Tokarick (2005), to mention a few. Taylor and Arnim (2006), criticize that the models are designed in such a way that "the price system" will always respond to

\footnotetext{
6 The findings include the baseline values in 2014 and the yearly value difference from the baseline expressed in US\$ billion at 2007 prices.
}

liberalization in a way that leads to an increase in overall well-being. Other studies which supported the criticism to these assumptions include Raza et al (2014), Charlton and Stiglitz (2005). Further, Panagariya and Duttagupta (2001) argue that the inclusion of the "Armington assumption" in all CGE models implies that there exists "product differentiation" which indicates that no country, howsoever small, produces something which is also produced by another country in the world. This implies that even when the price changes, no country can ever shift from exporting to importing a commodity. Most importantly, the model considers different assumptions with the GTAP Database and fails to capture the vertical intra-industry trade, and only captures the change in horizontal intra-industry trade across countries. Taken all these criticisms into account, the model grossly overestimates the rise in exports, GDP and employment, during the post-tariff elimination period.

\section{DATA AND METHODOLOGY}

This study uses the World Bank's World Integrated Trade Solution (WITS) Database. This database contains trade data for all the countries under a different nomenclature viz. at the two-digit, four-digit, and six-digit level. We use the HS-classified nomenclature at the sixdigit level in order to estimate the impact of the removal of tariffs on Indonesia's trade, i.e. both exports and imports. The purpose of using the six-digit HS classification is to estimate the gain and loss for each product at a disaggregation level. The six-digit HS classification is undertaken to find a disaggregated product level estimation. Other estimations such as trade patterns and tariff structures are also based on the HS classification, as reported in the WITS Database. 
Considering the criticism of CGE modeling, for the present purpose this study uses the SMART simulation which is based on a partial equilibrium approach. The main advantages of this approach are it needs a trade policy (tariff) and a couple of behavioral parameters (elasticities) to estimate the market access. It allows for estimating the tariff reduction at a much-disaggregated level, for example, the implications of removing tariffs on broken rice (at the HS six-digit disaggregation). This is an appropriate method, as such a disaggregated product level estimation is not possible with any other model.

\section{Rationale and Theoretical Background of SMART Simulation}

SMART simulations undertake a market access analysis based on the partial equilibrium. A market access analysis is used to anticipate the potential gains and losses of different trade policy reforms (i.e. tariff changes) on an economy. A SMART simulation, when included in WITS, can estimate the impact of a trade reform (both at home and abroad) on trade flows (export, imports, trade creation, and diversion) along with world prices, revenues, and economic welfare. The advantage of using the partial equilibrium approach (SMART simulation) is twofold. First, it requires a minimal dataset, viz. trade flow data, tariffs and other behavioral parameters such as elasticities. Second, it allows the estimation at a more disaggregated level, for example, the implications of removing tariffs on broken rice (at a HS six-digit disaggregation) which is not possible under the general equilibrium framework (WITS SMART Manual 2014, World Bank).

The trade effect of the SMART modeling framework is based on the fact that any changes in tariffs (trade policy) not only affect the price of the composite goods but also the relative price of the different varieties. A tariff shock affects the trade flows (i.e. imports from different sources), and it decomposes those total trade effects to trade's creation and diversion. In the present case, a reduction/elimination in tariffs, which will increase imports more from the TPP partners to Indonesia, is known as the trade creation effect. Second, the imports further increase from the TPP partners by diverting them away from the rest of the world (since imports from countries other than the TPP countries are relatively expensive) since the TPP negotiation is a preferential tariff for the countries in the negotiation. The theoretical illustration of SMART can be explained in the following steps.

Suppose Indonesia imports quantity A from the TPP countries and quantity $\mathrm{B}$ from the rest of the world, which is shown by $\mathrm{E}$, the intersection between the composite quantity $\mathrm{q}$ and the relative price line (Figure 1). Now, eliminating the tariff for TPP countries reduces its relative price compared to the rest of the world. Hence, the relative price line becomes steeper (Figure 2) and leads to a new equilibrium $\mathrm{E}_{1}$ where the imports from TPP countries would increase to $\mathrm{A}_{1}$ and the imports from the rest of the world systematically decreases to $B_{1}$. This trade diversion is calculated in the SMART simulation with the WITS Database.

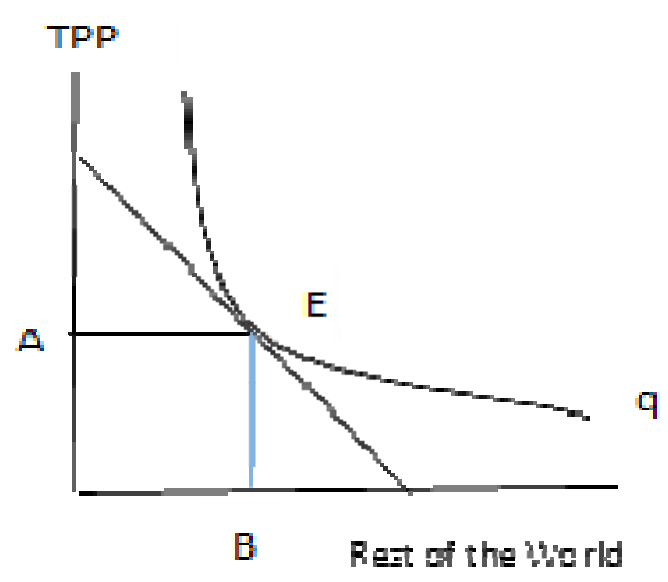

Figure 1. 


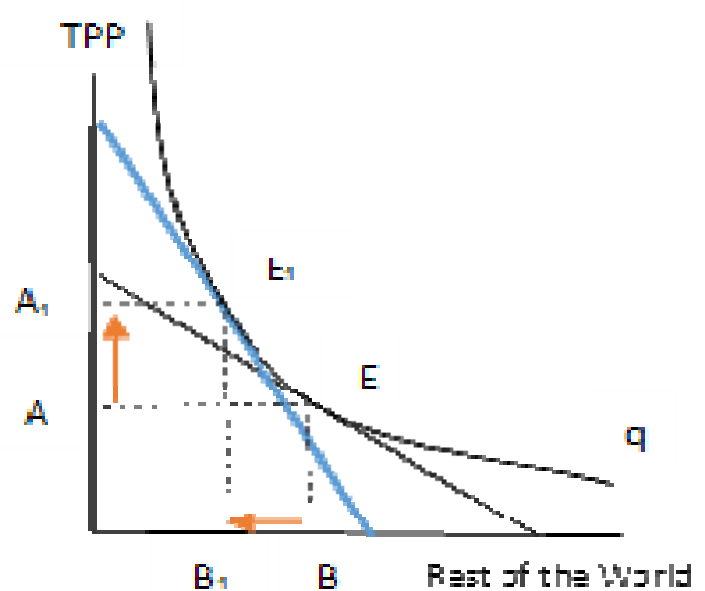

Figure 2.

Tariff concessions to TPP members would lower the domestic prices of the commodities imported from the TPP compared to imports from the rest of the world. This causes a revenue effect which allows it to reach a higher composite quantity curve $\mathrm{q}_{1}$ where the country can import more of the varieties from the TPP countries $\left(A_{1}\right.$ to $\left.A_{2}\right)$ as shown in Figure 3.

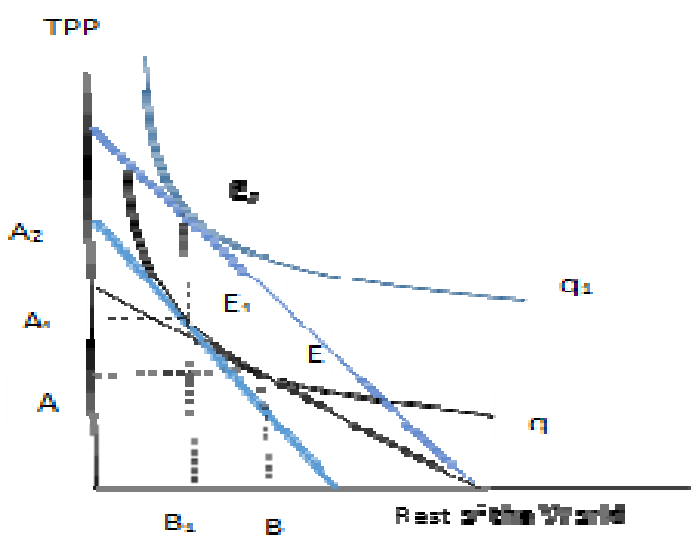

Figure 3.

SMART simulation in WITS is designed in such a way that a tariff reduction by the host country (i.e. Indonesia) will enjoy both a positive trade diversion ( $A$ to $A_{1}$ ) and trade creation $\left(A_{1}\right.$ to $\left.A_{2}\right)$. On the other hand, all the other trade partners (the rest of the world) will suffer from a negative diversion effect ( $B$ to $B_{1}$ ) and no trade creation effect, as shown in Figure 3.
SMART simulations are appropriate to use for the TPPA 12 analysis, as only a few products have high tariffs in many of the member countries, and hence implications for removing these tariffs on exports, imports, trade creation, and trade diversion. This also resolves several “aggregation biases”. Using SMART simulations, we first estimate the impact of the removal of all the six digit product level tariffs in the TPPA12 countries. The existing applied tariffs are used and all the import tariffs among the TPPA12 countries are brought down to zero, while tariffs with respect to the excluded countries remain the same. It is important to note that there are some limitations associated with this approach. First, as it is a "partial" model of the economy, the analysis is only done on a predetermined number of economic variables. Second, the result of the partial equilibrium analysis applies to only that product/sector and ignores inter-sectoral linkages and ignores the interactions between various markets. Third, the approach misses the existing constraints that apply to the factors of production and their movement across the sector.

\section{Indonesia's Trade Pattern with the TPP Countries}

International trade has made an increasingly significant contribution to economic growth for the Indonesian economy (Feridhanusetyawan and Pangestu 2004). Ever since the economic reforms of the 1980s focusing on trade, banking, investment, and capital account liberalizations, the Indonesian economy has experienced two big economic crises, namely the Asian financial crisis of 1997/98 and the global financial crisis of 2008/09. Both these crises derailed Indonesia's economy for a sustained period, particularly adversely affecting its exports because of the currency crisis. Despite these crises Indonesia's GDP growth averaged 5.35\% 
from 2000 until 2016, a higher growth compared to other major developing countries in the region, such as Malaysia and Thailand (World Bank Database). Exports played an important role in this regard, registering an annual average growth by 5.9\% during the period 2001-2014 (World Bank Microdata).

In terms of trade, Indonesia has increased its trade openness, explored several trade opportunities and increased its significant trade ties with many countries in the region and world (Suryahadi et. al. 2012). Over time, trade barriers were relaxed and it became more globally integrated (Chandra, 2006; Pangestu et al 2015). Trade has played a significant role in Indonesia's impressive growth and it is now ranked as the $28^{\text {th }}$ largest exporting country in the world (World Bank) The gradual reforms via deregulation and liberalization have increased trade in both its volume and share with many countries in the world (Chandra, 2006; Pangestu et al 2015). In absolute terms, Indonesia's merchandised trade increased to US\$354 billion in 2014 from a mere US\$87 billion in 2001, an estimated $40.7 \%$ growth in terms of the trade to GDP ratio (based on WITS database, World Bank). Its bilateral trade with China remained the highest, followed by Japan and Singapore during 2011-2014. About three-fourths of its total trade is with Indonesia's the top ten trade partners, of which four out of the top five trade destinations are part of the present TPP signatories (Table 1).

More segregated data shows that Indonesia's trade share with Japan has increased significantly ever since the latter's increased focus on Asia. Japan remains as its major export destination and China remains as the top import destination followed by Singapore and Japan, by the end of 2014 (based on WITS Database, World Bank). Indonesia's export growth to the present TPP bloc, since 2001, remained positive until the onset of the financial crisis in 2008. The post-crisis period saw a drastic decline, in both exports and imports, in 2009, with both its major trading partners and the present TPP signatories such as Japan, the USA, and Singapore. The key mechanism through which the crisis affected the Indonesian economy changed the export and import volumes, primarily as a result of the contraction in world demand/export markets. Retrenchments occurred in many of the exportoriented manufacturing firms of Indonesia. In value terms, exports to Japan fell by $49 \%$ followed by Singapore (25\%) and the US (20\%). Similarly, during the same period, Indonesia's imports from Japan fell by $54 \%$, followed by Singapore (40\%) and the US (11\%). The key trade relations with these countries further strengthened post 2009 until the year 2011, and fell back after that. In terms of the balance of trade, Indonesia's exports to the TPP parties remained higher than its imports since the year 1991, except for in 2012, showing a positive trade balance with the TPP countries.

Table 1. Indonesia's Trade with Top 10 countries during 2011-2014 (in US\$ billions)

\begin{tabular}{lccc}
\hline \multicolumn{1}{c}{ Countries } & $\begin{array}{c}\text { Total } \\
\text { Trade }\end{array}$ & $\begin{array}{c}\text { Export } \\
\text { Total }\end{array}$ & $\begin{array}{c}\text { Import } \\
\text { Total }\end{array}$ \\
\hline China & 200.9 & 84.8 & 116.1 \\
Japan & 192.6 & 114.1 & 78.5 \\
Singapore & 171.8 & 69.0 & 102.8 \\
United States & 103.4 & 63.7 & 39.7 \\
Korea, Rep. & 101.9 & 53.5 & 48.4 \\
Malaysia & 89.5 & 42.7 & 46.8 \\
India & 67.7 & 51.1 & 16.5 \\
Thailand & 66.7 & 24.4 & 42.3 \\
Other Asia, nes & 42.3 & 25.1 & 17.2 \\
Australia & 41.0 & 19.8 & 21.2 \\
Top 10 countries & 1077.7 & 548.2 & 529.6 \\
World & 1485.3 & 752.1 & 733.2 \\
\hline Top 10 countries as & $\mathbf{7 2 . 6}$ & $\mathbf{7 2 . 9}$ & $\mathbf{7 2 . 2}$ \\
\% of the world & & & \\
\hline
\end{tabular}

Source: WITS Database, World Bank. Ranking is based on the total trade with Indonesia 


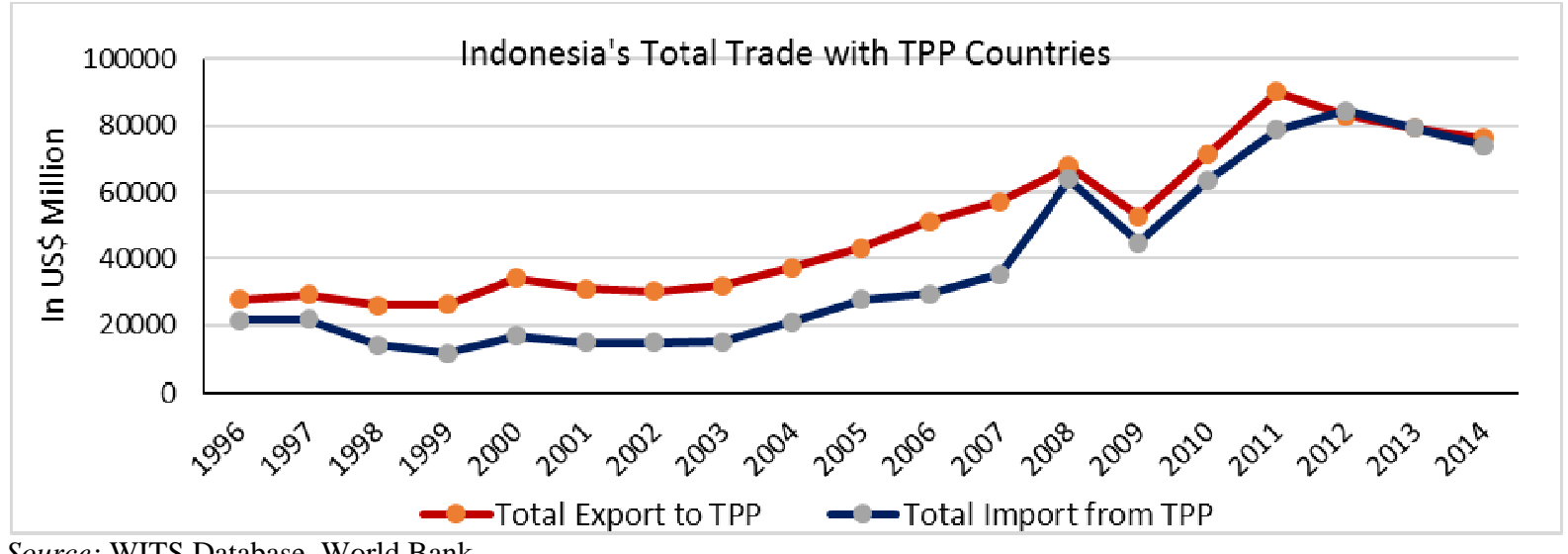

Source: WITS Database, World Bank

Figure 4. Indonesia's Total Exports and Imports from the TPP Countries

During the first half of the nineties, more than half (about 58\%) of Indonesia's total trade was with the present TPP signatories. However, it is evident that Indonesia's increased regional and bilateral trade negotiations with several countries have diverted its trade share with the present TPP signatories by a significant margin, estimated to be by more than ten percentage points compared to the late nineties (World Bank Database). Despite this, the TPP countries remain the most significant partners to the total trade value of Indonesia. In absolute terms, by the year-end 2014, the existing trade value with the TPP amounts to US\$150 billion, an increase of $21 \%$ over the year 2010 . The exports to these countries recorded marginally higher (US\$76 billion) than the import (US\$74 billion) by the year-end 2014. Its total trade share with the developed TPP partners has declined over the years from about $93 \%$ during the nineties to $85 \%$ during 2001-2010, and then further to $81 \%$ during 2011-2014. On the other hand, the average annual growth of Indonesia's trade with the developing TPP countries increased at the rate of $16 \%$ since the year 1991. Even though it is among the developing TPP, Indonesia exported the most to Malaysia followed by Vietnam during 1991-2014, but the average rate of growth of trade with Peru (44\%) is the highest, followed by Brunei (38\%), Vietnam
(18\%) and Malaysia (17\%) during the same period.

At the product level, Indonesia's export basket to the TPP countries is concentrated on a few specific products. The top ten products in Indonesia's export basket comprise about twothirds of its total exports since the year 2001. About one-third of the total exports are dominated by mineral fuels, oils and products (HS27) to these countries. This product group (HS27) continued to be an important source of revenue for the Indonesian economy, despite the volatility in the price of oil over the years. Falling oil prices in the early 1980s gradually declined its importance in trade and the government sought to develop non-oil sources of export revenue (Goeltom 2007). The government's supportive policy towards industrialization and trade liberalization again accelerated the economy towards greater trade involving other products. Despite all the strategic reforms and deregulations, oil and fuel products remained as the major trade component with the TPP countries all through the years, followed a distance second by electrical machinery, equipment, and parts (HS85). Similarly, the TPP partners contributed a significant share to Indonesia's import basket, but there is a marginal decline in its imports compared to the nineties. However, in absolute 
Table 2. Indonesia's Merchandise Trade with TPP Partners (US\$ millions)

\begin{tabular}{|c|c|c|c|c|c|c|c|c|c|c|}
\hline Countries & $\begin{array}{c}\text { Export } \\
\text { in } \\
1991\end{array}$ & $\begin{array}{c}\text { Export } \\
\text { in } \\
2014\end{array}$ & $\begin{array}{c}\% \\
\text { increase } \\
\text { in Exp. } \\
\text { Value }\end{array}$ & $\begin{array}{c}\text { Import } \\
\text { in } \\
1991\end{array}$ & $\begin{array}{c}\text { Import } \\
\text { in } \\
2014\end{array}$ & $\begin{array}{c}\% \\
\text { increase } \\
\text { in Imp } \\
\text { Value }\end{array}$ & $\begin{array}{l}\text { Total } \\
\text { Export } \\
(1991- \\
2014)\end{array}$ & $\begin{array}{l}\text { Total } \\
\text { Import } \\
(1991- \\
2014)\end{array}$ & $\begin{array}{l}\text { Total } \\
\text { Trade } \\
\text { (1991- } \\
2014)\end{array}$ & $\begin{array}{c}\text { Trade \% } \\
\text { with TPP } \\
\text { partner } \\
1991-2014\end{array}$ \\
\hline Japan & 10767 & 23127 & 115 & 6327 & 17008 & 169 & 419414 & 223697 & 643111 & 34.5 \\
\hline Singapore & 2410 & 16752 & 595 & 1698 & 25186 & 1383 & 199500 & 231780 & 431280 & 23.1 \\
\hline United States & 3508 & 16560 & 372 & 3397 & 8189 & 141 & 227977 & 127746 & 355723 & 19.1 \\
\hline Malaysia & 342 & 9732 & 2747 & 407 & 10855 & 2569 & 97381 & 93547 & 190928 & 10.2 \\
\hline Australia & 628 & 4962 & 690 & 1378 & 5648 & 310 & 58304 & 66146 & 124451 & 6.7 \\
\hline Vietnam & 151 & 2451 & 1521 & 87 & 3418 & 3820 & 22302 & 19219 & 41521 & 2.2 \\
\hline Canada & 172 & 755 & 339 & 354 & 1860 & 425 & 11715 & 21351 & 33067 & 1.8 \\
\hline New Zealand & 27 & 481 & 1651 & 117 & 836 & 613 & 5460 & 8616 & 14076 & 0.8 \\
\hline Brunei* & 40 & 100 & 154 & 7 & 594 & 8911 & 946 & 11614 & 12561 & 0.7 \\
\hline Mexico & 57 & 851 & 1400 & 81 & 187 & 130 & 7837 & 3071 & 10908 & 0.6 \\
\hline Chile & 9 & 178 & 1957 & 118 & 242 & 106 & 2573 & 4260 & 6833 & 0.4 \\
\hline Peru & 0 & 210 & 128237 & 2 & 67 & 2643 & 1220 & 820 & 2040 & 0.1 \\
\hline Total TPP & 18110 & 76161 & 321 & 13973 & 74089 & 430 & 1054629 & 811868 & 1866497 & 100.0 \\
\hline \multicolumn{11}{|l|}{ Total TPP as } \\
\hline$\%$ of World & 62.1 & 43.3 & 63.6 & 54.0 & 41.6 & 73.2 & 48.9 & 46.4 & 47.7 & \\
\hline
\end{tabular}

Source : Authors estimation from WITS Database, World Bank.

Note : Ranking is based on 1991-2014 aggregate trade with TPP countries

terms, it has increased from over US\$100 billion in the first half of the nineties to nearly US\$317 billion during 2011-14. Singapore remains as the top import destination followed by Japan and the USA since the year 1991.

At the commodity level, the composition of imports from the TPP remains much the same, with mineral fuels, oils, and products (HS27), constituting about $28 \%$ of the total import value during 2001-2014. In the year 2014, oil and gas imports rose sharply, coupled with the negative growth in their export, partially offsetting the overall contribution of this sector to the trade balance. A marginal drop in the total export value of fuel and oil products could be due to the currency turmoil and the weak macroeconomic fundamentals of many economies, leading to a fall in the global oil price. Similarly, the non-oil imports declined by more than $4 \%$ in the year 2014, part of the decline was in the import of manufactured goods, but most of the decline was due to non-manufactured items (Figure 5 and Table 3).

\section{Indonesia's Trade Agreements and Tariff structure: Special References to TPP}

Indonesia extends Most Favoured Nation (MFN) treatments to all WTO members. It has systematically undertaken several steps to reduce its barriers to trade, including promoting investment, streamlining procedures at the borders and customs reform. The most prominent of all is the introduction of Indonesia's National Single Window (NSW) in 2007, which allows for the online processing of customs documentation, applications for licenses, and duty payments. An estimated 90\% of the trade entering and leaving Indonesia is streamlined through the NSW (World Bank, Trade Policy Review 2012). Indonesia has enacted new laws relating to its Sanitary and Pshyco-sanitary System regime, export financing and special economic zones. The major objective of its trade policy is to increase the export of non-oil products, strengthen the domestic market and national distribution channels, shift into higher value-added activities and strengthen the 


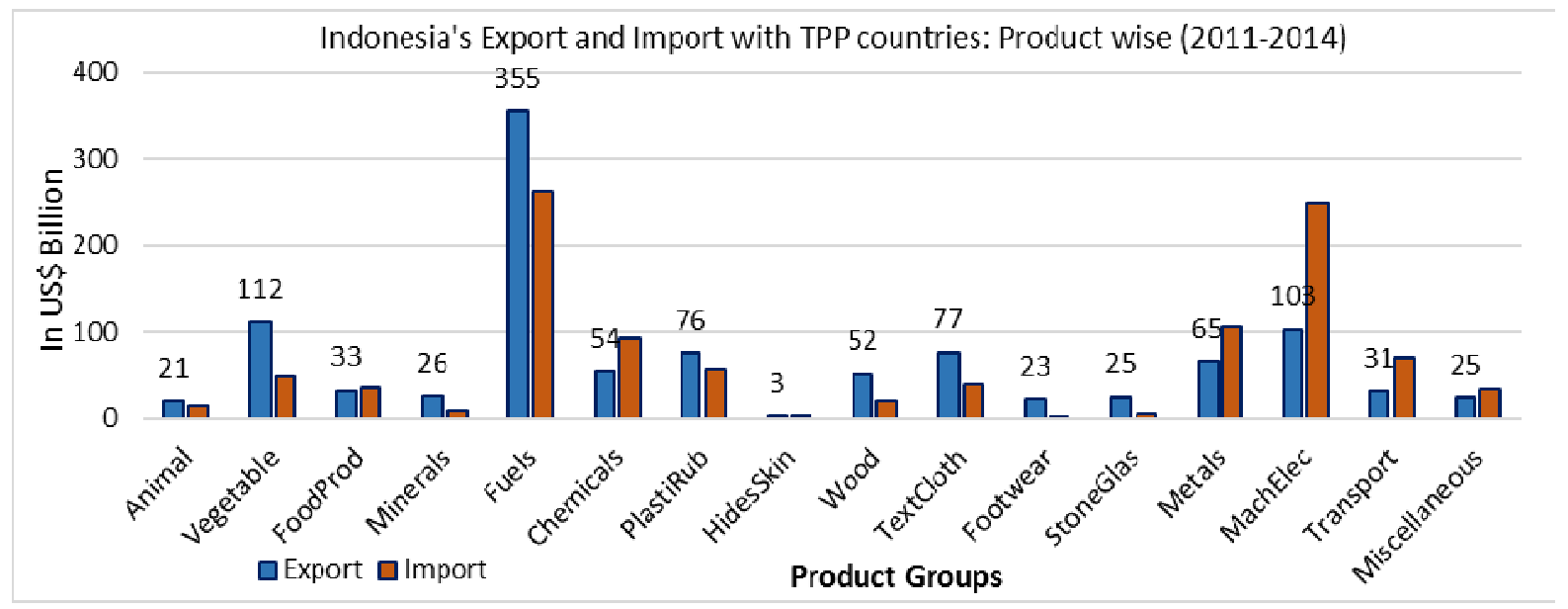

Source: estimated from WITS Database, World Bank.

Figure 5. Indonesia's Exports and Imports to TPP countries: Major Product groups (in US\$ billions)

Table 3. Share of top 10 products in the total imports of Indonesia from the TPP countries (percentage)

\begin{tabular}{lccccc}
\hline \multicolumn{1}{c}{ Product Name and Code } & 2014 & $2001-2005$ & $2006-2010$ & $2011-2013$ & $2001-2014$ \\
\hline Mineral fuels, oils and products of their... (27) & 29.4 & 23.5 & 28.6 & 28.6 & 27.9 \\
Nuclear reactor, boilers and machinery... (84) & 13.8 & 16.4 & 14.3 & 14.4 & 14.6 \\
Electrical machinery, equipment \& parts (85) & 8.3 & 3.9 & 7.6 & 8.3 & 7.4 \\
Vehicles other than railway/ tramway rolling & & & & & \\
stock \& parts (87) & 3.1 & 7.4 & 4.4 & 4.2 & 4.6 \\
Iron and Steel (72) & 4.3 & 3.5 & 4.3 & 4.7 & 4.3 \\
Organic Chemicals (29) & 3.7 & 6.3 & 3.8 & 3.0 & 3.8 \\
Plastics and Articles thereof (39) & 4.8 & 3.1 & 3.3 & 4.1 & 3.8 \\
Cereals (10) & 3.1 & 3.3 & 3.1 & 3.5 & 3.2 \\
Articles of Iron and Steel (73) & 2.7 & 2.6 & 2.6 & 2.5 & 2.6 \\
Aircrafts, spacecraft's \& parts (88) & 0.4 & 0.8 & 2.8 & 2.6 & 2.2 \\
Top 10 products Import to TPP as \% of total & & & & & \\
Import to TPP & 73.5 & 70.7 & 74.9 & 75.9 & 74.5 \\
Top 10 products import to TPP as \% of total & & & & & \\
import to the world & 30.3 & 33.1 & 35.6 & 32.7 & 33.5 \\
\hline
\end{tabular}

Source : estimated from WITS Database, World Bank.

Note : Ranking is based on 2001-2014 aggregate trade with TPP countries

industrial sector to act as the driving force for the economy, supported by the agriculture, marine, and mining sectors.

Indonesia, an original member of the WTO, is a participant in the WTO Information Technology Agreement (ITA) and signatory to the General Agreements on Tariff and Trades (GATTs) Fourth Protocol on Telecommunications and Fifth Protocol on Financial Services. It has undertaken several trade agreements to strengthen and expand its trade, investment and economic cooperation relationships with some countries and regions of the world. As per the latest available data, Indonesia has eight FTAs (six regional and two bilateral) along with one Preferential Trade Agreements (PTA with a group of eight developing countries. Indonesia's FTAs are with the ASEAN free trade area, 
ASEAN Free Trade Agreement (ASEAN Economic Cooperation and ASEAN Trade in Goods Agreement); ASEAN-Australia and New Zealand (AANZFTA), ASEAN-China, ASEANIndia, ASEAN-Japan, and ASEAN-Korea, Indonesia-Japan EPA (Economic Partnership Agreement) and Indonesia-Pakistan FTA. In addition, Indonesia has launched six bilateral negotiations (with India, Australia, Chile, the European Union, Regional Comprehensive Economic Partnership and South Korea), one through ASEAN (ASEANHong Kong, China) and one plurilateral (with a group of eight developing countries that includes Bangladesh, Indonesia, Malaysia, Pakistan, Egypt, Iran, Nigeria and Turkey). Indonesia has also signed the Trade Preferential System of the Organization of the Islamic Conference (TPSOIC), but it did not come into effect. Brunei, a part of the present TPP, is also a member of the TPSOIC. Indonesia is continuing to work together with these countries towards achieving the end goals of each signed agreement.

In general, Indonesia has much lower tariffs than other developing countries in the world (Soesastro and Basri, 2005). As per the 2003 tariff schedule in HS02 nomenclature, Indonesia has bound $95 \%$ of its tariffs, and nearly $72 \%$ of these are bound at $40 \%$ or above (TPR 2013). Indonesia's MFN tariff ranges from duty-free to $150 \%$ on some products. Alcoholic beverages (34 lines) and food preparations (not elsewhere specified, seven lines) face the highest tariff, followed by the second highest tariff rate of $90 \%$ (wine and shandy), and all the other tariffs are below $40 \%$. The government had made several efforts to achieve its tariff harmonization programs, including liberalization of some higher tariffs. In 2012, the government replaced the nomenclature of its tariff book ${ }^{7}$ that resulted in a $10 \%$ reduction in the total number of MFN applied tariff lines, compared to Indonesia's previous HS2007 nomenclature ${ }^{7}$. The simple average applied tariff (import tariff for all countries) of Indonesia, for all products, has declined by a significant margin to $6.7 \%$ in 2013, as compared to $9.5 \%$ in 2006. For the present TPP signatories, the average effectively applied tariff (import tariff) of Indonesia, for all products, is $4.6 \%$, much lower than that of other countries. The same for applies to WTO-HS agricultural products and WTO-HS industrial products, which are at $4.1 \%$ and $4.6 \%$ respectively. It is interesting to note that Indonesia's tariff for the ASEAN countries (party to TPP) is nearly zero. These ASEAN countries (Brunei, Malaysia, Singapore, and Vietnam) together account for more than $54 \%$ of Indonesia's total imports from the present TPP countries. On the other hand, Indonesia faces much lower tariffs for its export to the present TPP countries, averaged at $2.5 \%$ for all products (Table 4).

What is intriguing about the joining, or the non-joining, of Indonesia is that it already has existing FTAs, or has launched trade agreements with two-thirds of the present TPP signatories. (Table 4). Whether these FTAs have and will result in gains for Indonesia or not is still an issue for discussion. But, with the TPP shaping for action, the projection of its effects on Indonesia's trade and welfare is a matter of real concern. Therefore, the growing trend of mega FTAs like the TPPA has necessitated an early analysis of its likely trade impacts on Indonesia, regardless of it joining or not joining these FTAs.

\footnotetext{
${ }^{7}$ The nomenclature changed from Indonesian Entry Custom Tariff Book (BTBMI) to the Indonesian Custom Tariff Book (BTKI) in 2012. This is formulated in accordance with the World Custom Organization HS2012 nomenclature and the ASEAN Harmonized Tariff Nomenclature (AHTN).
} 
Table 4. Indonesia's FTA status with TPP Countries and Existing Tariff Rate

\begin{tabular}{lcc}
\hline \multicolumn{1}{c}{ Partner Name } & FTA Status & Applied Tariff Rate \\
\hline Australia & In effect through AFTA & 7.41 \\
Chile & Launched but not signed & 9.54 \\
Canada & No FTA & 7.31 \\
Brunei & AFTA & 0.00 \\
Mexico & No FTA & 7.55 \\
New Zealand & In effect through AFTA & 7.78 \\
Japan & Bilateral and through AFTA & 6.99 \\
Malaysia & AFTA & 0.08 \\
Peru & No FTA & 8.71 \\
Singapore & AFTA & 0.43 \\
United States & No FTA & 7.05 \\
Vietnam & AFTA & 0.04 \\
\hline Source: FTA status is taken from Asian Development Bank and Tariff from WITS, World Bank
\end{tabular}

4. An implication of Tariff Liberalization on Indonesia during the post TPPA period

Indonesia's concerns can be addressed in line of the present trade agreements with the countries involved in the agreement. Indonesia enjoys trade deals with seven countries amongst the present TPP signatories, of which four countries (Brunei, Malaysia, Singapore and Vietnam) belong to AFTA, to which Indonesia is also a party, and it also has one regional (ASEANAustralia and New Zealand) and one bilateral economic partnership agreement with Japan. These seven countries together account for more than 75\% (about US\$58 billion in 2014) of Indonesia's exports to the present TPP countries. If Indonesia remains out of it, the present twelve quite diverse members of the TPP, with the USA at the helm of affairs, might face difficulties in exporting to the majority of the TPP partners, despite having trade deals with more than half of them.

Taking this into consideration, the present study examines the likely gain and loss to Indonesia using the simulation result in two different scenarios. First, the gain/loss in exports/imports if Indonesia becomes a part of the present TPP signatories, and second, what would be the gain/loss if it remains out of the present TPP. We first estimate the impact of the removal of all six digit product level tariffs in the TPPA12 countries. The existing applied tariffs are used and all tariffs among the TPPA12 countries are brought down to zero. The rationale behind the use of this approach is based on the fact that it allows for the estimation of tariff reductions at the six digit disaggregation level. The model not only estimates the extent of the imports that may come from the TPP members into Indonesia if all tariffs are brought down to zero, but is also able to provide the results at the product level on the trade diversion, i.e. from which non-TPP countries will the imports be diverted.

\section{a. Scenario 1: If Indonesia Joins TPP-}

The estimation based on the 2014 simulation reveals that, in the case where Indonesia joins the TPP bloc, the exports would rise by over US\$3.763 billion annually, as against a rise in imports of over US\$3.784 billion, leaving a net deficit of US\$19 million in the balance of trade with the present TPP bloc. Its imports are likely to increase most from Japan (US\$2.482 billion) followed by the USA (US\$878 million) and 
Australia (US\$384 million). However, the export rise would be the highest to the USA (US\$2.331 billion) followed by Malaysia (US\$705 million) and Vietnam (US\$241 million). The combined effect shows that Indonesia will experience the highest trade deficit with Japan (US\$2.360 billion) followed by Australia (US\$372 million) and New Zealand (US\$42 million) and a trade surplus with all the other TPP countries. In particular, it will experience the highest trade surplus with the USA (US\$1.453 billion) followed by Malaysia (US\$739 million) and Vietnam (US\$251 million).

At the product level, revenue losses with the TPP countries would remain highest for mineral fuels, oils and products (HS27; US\$426 million) followed by boilers, machinery and mechanical products (HS84; US\$385 million) and vehicles other than railway rolling stock, tramway rolling stock (HS87; US\$335 million) and electrical machinery equipment and parts (HS85; US\$196 million). On the other hand, the gain in revenue would be highest for the product HS87 (US\$784 million) followed by HS84 product (US\$735 million) and iron and steel (HS72; US\$207 million).

During the initial phase, Indonesia may provide some transitional safeguard measures for the industries which are severely affected, due to the increased imports as a result of the steep tariff cuts. But this support is only for two years, with a one-year extension, and must be progressively liberalized if they last longer than a year. At the same time, Indonesia may have to provide mutually agreed compensation to the countries if it imposes transitional safeguard measures for its domestic industries, as per the trade remedies rule under the TPP.

Table 5. Indonesia's Rise in Export and Import if it takes part in TPP (in US\$ '000)Countries

\begin{tabular}{lccc}
\hline & $\begin{array}{c}\text { Rise in Indonesia's } \\
\text { Import }\end{array}$ & $\begin{array}{c}\text { Rise in Export from } \\
\text { TPP Partners }\end{array}$ & $\begin{array}{c}\text { Indonesia's Net Trade } \\
\text { Balance }\end{array}$ \\
\hline Australia & 383682 & 11968 & -371714 \\
Brunei & -21 & -52 & -31 \\
Canada & 69762 & 145307 & 75545 \\
Chile & 7507 & 23714 & 16207 \\
Japan & 2488347 & 128485 & -2359862 \\
Malaysia & -34145 & 704665 & 738810 \\
Mexico & $\mathbf{2 4 6 2 7}$ & 144756 & 120129 \\
New Zealand & 52959 & 10876 & -42083 \\
Peru & 1123 & 24349 & 23226 \\
Singapore & $-\mathbf{7 6 8 9 1}$ & -5 & 76886 \\
United States & 877612 & 2330723 & 1453111 \\
Vietnam & -10278 & 240853 & 251131 \\
\hline \multicolumn{1}{c}{ Total TPP } & $\mathbf{3 7 8 4 2 8 6}$ & $\mathbf{3 7 6 5 6 3 9}$ & $\mathbf{- 1 8 6 4 7}$ \\
\hline
\end{tabular}

Source: Estimated using SMART simulations 
Table 6. Indonesia's tariff loss due to the increased imports if it takes part in TPP:

Top ten products (in US\$ millions)

\begin{tabular}{cclcc}
\hline $\begin{array}{c}\text { Sl. } \\
\text { No. }\end{array}$ & $\begin{array}{c}\text { Product } \\
\text { HS code }\end{array}$ & \multicolumn{1}{c}{ Product Description } & Import Change & $\begin{array}{c}\text { Tariff (Loss In } \\
\text { Revenue) }\end{array}$ \\
\hline 1 & 27 & Mineral fuels, mineral oils and products of their & 29.7 & -426.2 \\
2 & 84 & boilers, mach. \& mechanical & 486.8 & -385.0 \\
3 & 87 & Vehicles other than railway, tramway Rolling & 564.7 & -334.5 \\
4 & 85 & Electrical machinery and equipment and parts there & 97.2 & -196.0 \\
5 & 72 & Iron and Steel & 130.5 & -126.5 \\
6 & 39 & Plastics and articles thereof & 111.6 & -118.6 \\
7 & 73 & Articles of iron or steel & 114.8 & -91.7 \\
8 & 29 & Organic chemicals & 36.0 & -68.8 \\
9 & 10 & Cereals $\quad 79.3$ & -57.5 \\
10 & 22 & Beverages, spirits and vinegar & 20.3 & -55.5 \\
\hline \multicolumn{2}{c}{ Total (1-97) } & All Products & $\mathbf{2 5 8 0 . 1}$ & $-\mathbf{2 4 5 3 . 7}$ \\
\hline
\end{tabular}

Source: Estimated using SMART simulations

Table 7. Indonesia's gain in revenue due to the increased export if it takes part in TPP: Top ten products (in US\$ millions)

\begin{tabular}{cclc}
\hline Sl. No & $\begin{array}{c}\text { Product HS } \\
\text { Code }\end{array}$ & \multicolumn{1}{c}{ Product Description } & $\begin{array}{c}\text { Increase In Exp. } \\
\text { Revenue }\end{array}$ \\
\hline 1 & 87 & Vehicles other than railway, tramway Rolling & 784.2 \\
2 & 84 & boilers, mach. \& mechanical & 735.2 \\
3 & 72 & Iron and Steel & 207.3 \\
4 & 73 & Articles of iron or steel & 186.8 \\
5 & 39 & Plastics and articles thereof & 180.8 \\
6 & 85 & Electrical machinery and equipment and parts there & 165.9 \\
7 & 21 & Miscellaneous edible preparations & 119.7 \\
8 & 38 & Miscellaneous chemical products & 112.0 \\
9 & 17 & Sugar and Sugar Confectionery & 103.1 \\
10 & 10 & Cereals & 93.3 \\
11 & 40 & Rubber and Article thereof & 91.3 \\
\hline \multicolumn{2}{c}{ All Products } \\
\hline
\end{tabular}

Source: Estimated using SMART simulations

\section{b. Scenario 2: If Indonesia remains out-}

The second scenario shows Indonesia's trade diversion, i.e. the change in exports with the TPP countries in its absence. The post TPP tariff liberalization would lower the trade costs, allowing consumers to access cheaper goods from these TPP partners. Similarly, the lower tariffs would allow producers to get access to cheaper imported materials or supplies, which in turn would reduce the prices of the finished goods in these markets; effectively affecting
Indonesia's exporting potential to the TPP bloc. The simulation estimation shows that if Indonesia remains out, there is a likely decline in its exports by US\$413 million annually with the TPP countries, because of the trade diversion. The highest export loss is predicted to be with the USA, followed by Malaysia and Australia. The cumulative export loss with these top three countries would amount to more than $81 \%$ of the total export loss with the TPP countries during the post TPP implementation. 
Table 8. Total Loss of Indonesia with the TPP Countries if it remains out of TPP (In US\$ millions)

\begin{tabular}{lccc}
\hline \multicolumn{1}{c}{ TPP Countries } & $\begin{array}{c}\text { Trade Balance } \\
\mathbf{( 2 0 1 4 )}\end{array}$ & $\begin{array}{c}\text { Trade Balance Since } \\
\mathbf{1 9 9 1}\end{array}$ & Post TPP Export loss \\
\hline Australia & -685 & -7842 & -8.8 \\
Brunei & -494 & -10668 & -0.1 \\
Canada & -1105 & -9636 & -9.8 \\
Chile & -64 & -1687 & -2.7 \\
Malaysia & -1124 & 3834 & -104.9 \\
Japan & 6120 & 195716 & -49.1 \\
Mexico & 663 & 4767 & -29.7 \\
New Zealand & -355 & -3156 & -1.9 \\
Peru & 144 & 400 & -2.2 \\
Singapore & -8434 & -32280 & 0.0 \\
United States & 8372 & 100231 & -182.1 \\
Vietnam & -967 & 3084 & -21.6 \\
\hline \multicolumn{2}{r}{ Total } & 2071 & -413 \\
\hline Source: Estimated using SMART simulations & & &
\end{tabular}

Stated differently, the estimation reveals that the post TPP scenario would decrease the present trade surplus from US\$2 billion to US\$1.6 billion if Indonesia does not become a party to the TPP bloc. However, this does not take into account the "yarn forward rule" of origin in the TPP, which requires thread and fabric, etc. to come from TPP countries and therefore restricts the amount that existing TPP countries can increase their exports of clothing to the US.

\section{CONCLUSION}

Trade agreements seem to have benefited Indonesia's economy and its people in many ways over the years, even though it has an important cost for some people. The present findings, in the context of the joining or nonjoining of Indonesia, show that even with Indonesia's non-participation in the TPP, it will still have a trade surplus in goods of US\$1.6 billion with the TPP countries. However, if Indonesia becomes a party to the agreement, the goods trade surplus would turn into a trade deficit of US\$19 million. As evident from our findings, Indonesia's trade balance is likely to widen if it joins the TPP, compared to staying out of it. It is not clear where or how Indonesia can benefit from the TPP in a way that can compensate for the likely losses to Indonesia. For example, the TPP's intellectual property chapter alone will keep the prices of medicines and textbooks high in Indonesia for longer, and increase the cost of materials for Indonesian farmers and manufacturers (Sahu, 2016, Jakarta Post).

The tariff loss in the post TPPA without Indonesia is large, because of the trade diversion and can be attributed to two reasons. First, the tariff liberalization lowers the trade costs, allowing the consumers to access cheaper goods from these TPP partners. Second, the lower tariffs allow the producers to get access to cheaper imported materials or parts, which in turn reduce the prices of their finished goods. This may well affect Indonesia's exports to these countries, as the production of low-cost competitive products cannot happen overnight, given the fact that there exist bottlenecks in the infrastructure, including in transport, power, and water. 
Even with Indonesia's existing trade agreements, Indonesia may face difficulties to export to these markets under a new international standard of its own. Although Indonesia joining the TPPA may not offer many gains in terms of its trade balance, but opting out of it may cost more in the long run. In case the countries who have expressed their interest, viz. Thailand, the Philippines, Taiwan, Bangladesh, Laos, Cambodia, South Korea, and Colombia do join the club in the future, the trading loss could rise substantially and limit Indonesia's trade prospects with these Pacific Rim countries. Further, the cost could be even higher if Indonesia is unable to complete or withdraws from some of its ongoing trade negotiations. Along with the future trade limitations, Indonesia may also lose out on linking into global value chains, due to the TPP's rules on standards for labor and environmental policies. As the TPP gets bigger, Indonesian exports to the TPP markets may require additional testing, which increases the cost and time to access these markets, thereby undermining the competitiveness of Indonesian products in these markets.

The participation of big markets like the USA, Canada, Japan and Australia in the TPP, along with other developing countries may increase their capacity to influence WTO outcomes, and thereby limit Indonesia's future prospects of trade growth if it remains out. Most significantly, the TPP may isolate Indonesia from being a significant export partner with the US, Japan, Australia and New Zealand, with whom it enjoys preferential access.

Similarly, the TPP's investment chapter has strong protection for foreign investments, including providing investor-to-state dispute settlements with the most litigious investor in the world, the US, who have a $98 \%$ chance of a broad interpretation of their rights in these disputes, and the TPP sets no maximum limit on the damages the governments have to pay them (e.g. one country recently had 180 days to pay a foreign investor US\$50 billion under provisions equivalent to those in the TPP). These TPP investment chapter provisions are equivalent to those in Indonesia's bilateral investment treaties, which have proven to be so problematic that Indonesia is currently withdrawing from them. Indonesia will not be able to change these TPP rules if it joins the TPP. Considering all these factors, it is evident from the estimation that joining the TPPA will lead to a rise in imports, as compared to exports. But Indonesia's gain from other chapters of the TPP during the post TPP scenario will be clearer once it comes into effect by early 2018.

\section{REFERENCES}

Banga, R., \& Sahu, P. K. (2015). Trans-Pacific Partnership Agreement (TPPA): Implications for India's trade and investments. Center for WTO Studies Working Paper, Indian Institute of Foreign Trade. CWS/WP/200/24.

Banga, R. (2014). Trans-Pacific Partnership Agreement (TPPA): Implications for Vietnam's domestic value-added trade. Center for WTO Studies Working Paper, CWS/WP/200/ 19.

Banga, R. (2015). Trans-Pacific Partnership Agreement (TPPA): Implications for Malaysia's domestic value-added trade. Center for WTO Studies Working Paper, CWS/WP/200/ 18.

Bergsten, F. C. (2015). India's rise: A strategy for trade led growth. Trade and investment policy watch, Petersons Institute for International Economics, PIIE Briefing 15-4.

Bertram, G. \& Simon, T. (2014). Economic gains and costs from the TPP. Sustainability Council of New Zealand. February.

Chandra Alexander C. (2006). Indonesia and bilateral trade agreements. The Pacific Review. vol. 6(1), 1-28. 
Charlton, A.H. \& Stiglitz, J.E. (2005). A development-friendly prioritization of Doha round proposals. The World Economy, 28 (3), 293-312.

Cheong I. (2013) Negotiations for the TransPacific Partnership Agreement: Evaluation and implications for East Asian regionalism, ADBI Working Paper 428, Available at SSRN:

https://ssrn.com/abstract=2292899 or http:// dx.doi.org/10.2139/ssrn.2292899

Chow D.C.K. (2016). How the United States use the Trans-Pacific Partnership to contain China in international trade, Chicago Journal of International Law, 17(2), 370402.

Cororation C. B. \& David O. (2015). Potential economic effects on the Philippines of the Trans-Pacific Partnership. Global Issues Initiative, Working Paper No. 2014-1.

Deardorff, A. V. 2013. Trade implications of the Trans-Pacific Partnership for ASEAN and other Asian countries. Asian Development Review Conference, 01-02 August 2013, Manila.

Feridhanusetiawan T \& Pangestu M.(2004). Indonesian Trade Liberalization: Estimating the Gains. Bulletin of Indonesian Economic Studies, 39 (1), 51-74.

Gajdos, L. (2013). The Trans-Pacific Partnership and its impact on EU trade. DirectorateGeneral for External Policies, Policy Briefing, Report no DGEXPO/B/PolDep/ Note/2013_3.

Goeltom, M. S. (2007). Economic and fiscal reforms: The experience of Indonesia 19801996. In Essays in Macroeconomic Policy: The Indonesian Experience, PT Gramedia Pustaka, Jakarta, 489-506.

Kenichi, K. (2011). Determining priority among EPAs: Which trading partner has the greatest economic impact? Research Institute of Economic, Trade and Industry. Retrieved from http://www.rieti.go.jp/en/columns/a01_0318 .html
Panagariya, A. \& Duttagupta. (2001). The 'gains' from preferential trade liberalization in the CGEs: Where do they come from? In S. Lahiri, ed., Regionalism and Globalization: Theory and Practice, Routledge, pp.39-60.

Pangestu M. Rahardja S. \& Ing Y.L. (2015). Fifty years of trade policy in Indonesia: New World trade, old treatments. Bulletin of Indonesian Economic Studies, 51(2), 239261.

Petri, P. A. \& Michael G. P. (2012). The TransPacific Partnership and Asia-Pacific integration: policy implications. Peterson Institute of International Economics, Policy Briefs, No. PB12-16.

Petri P. A., Plummer M.G. \& Zhai F. (2011). The Trans-Pacific Partnership and the AsiaPacific integration: A quantitative assessment. East- West Centre Working Paper, Economic Series No. 119.

Petri Peter A. \& Plummer M. G. (2016) The economic effects of the Trans-Pacific Partnership: new estimates. Working Paper, 16-2, Peterson Institute for International Economics.

Raza, W., Grumiller, J, Taylor, L., Tröster, B. \& Arnim, R. V. (2014). Assess TTIP: Assessing the claimed benefits of the transatlantic trade and investment partnership. Austrian Foundation for Development Research.

Sahu P.K. (2016). Trans-Pacific Partnership: Should Indonesia join it or not? Insight, The Jakarta Post, February 18, Indonesia.

Soesastro H. \& Basri M.C. (2005). The political economy of trade policy in Indonesia. Centre for Strategic and International Studies, Economics Working Paper Series. WPE092.

Suryahadi A. Hadiwidjaja G. \& Sumarto S. (2012). Economic growth and poverty reduction in Indonesia before and after the Asian financial crisis. Bulletin of Indonesian Economic studies, 48 (2), 209227. 
Taylor, L. \& Arnim, R. V. (2006). Computable general equilibrium models of trade liberalization: The Doha Debate. Mimeo, New School for Social Research. Oxford: Oxfam GB.

Tokarick, S. (2005) Who bears the cost of agricultural support in OECD countries? World Economy, 28(4), 573-93.

Trade Policy Review (2012), World Trade Organisation World Bank.

Wits (2014), SMART Manual, World Integrated Trade Solution, World Bank.
World Bank Database (2017). World Bank Open Data. Retrieved from https://data.worldbank.org/

World Trade Organisation. (2013). Trade Policy Review-2013, Report by the Secretariat, Indonesia, Trade Policy Review Body.

Xin, Li. (2014). A general equilibrium analysis of the TPP free trade agreement with and without China, The Journal of Applied Economic Research, 8(2), 115-136. 